\title{
Evaluation of African black pear pulp and oil as ingredients in bread production
}

\author{
Onuegbu, N.C*., Onyeka, E.U. and Agbayi, D. \\ Department of Food Science and Technology, \\ Federal University of Technology, Owerri, Nigeria. \\ *Address for correspondence E-mail: tobuz2000@yahoo.com
}

ABSTRACT

\begin{abstract}
Bakery fat is important ingrredient that affects the rheological properties of bread crumb. In this work, African black peer pulp and pulp oil were used as substitutions to commercial bakery fat $0 \%, 25 \%, 50 \%, 75 \%$ and $100 \%$ levels of substitution. The results obtained show that significant difference $(p>0.05)$ occur between the sample and the control. The degree of differences observed in the proximate
\end{abstract}

composition and sensory characteristics increased as level of pear pulp substitution increased. However, significant differences ( $p>0.05)$ in sensory characteristics were only observed between the control and the pulp oil substituted sample at the higer levels $(75 \%, 100 \%)$ of substitution.

Keywords: African pear, pulp, oil, bread, bakery fat, proximate, sensory.

\section{INTRODUCTION}

$\mathrm{B}$ read is one of the food staples in Nigeria. It is consumed by people in every socio-economic class, and is acceptable to both children and adults. The major ingredients for bread making are flour, water, sugar, fat/oil, and yeast. Other ingredients such as milk powder; malt, mineral and salts may be added (Ihekoronye and Ngoddy, 1985). Recently the Nigerian government created awareness in the use of composite flours especially cassava, but few has been done in the area of substitution of the bakery fat with other fats/oils especially unrefined and nonhydrogenated oil (Badifu et al 2005). The bakery fat or shortening is an important ingredient that affects the rheological properties of the breadcrumb.

In this work, African black pear pulp and pulp oil were used as substitutes to the normal bakery fat. The African pear pulp is high in oil content (20$32 \%$ ) and the oil comprises of linoleic, oleic and palmitic acids (Omoti and Okiy, 1990; Kinkella and Bezard, 1993). In addition the pulp contains protein, moisture, carbohydrates, mineral elements, organic acids and vitamins (Omoti and Okiy, 1990). It is envisaged that addition of this fruit pulp in the bread recipe will not only supplement the bakery fat but will also improve the nutritional quality of the bread. African pear pulp has been successfully utilized in biscuit recipe (Mbofoung et al., 2002). However, as at now, there is no industrial/commercial process that utilizes this fruit though it is abundant in the rain forest region of South-Eastern Nigeria.

There is need to utilize African black pear fruit as an ingredient in already known food products as well as discover new products that can be made from this raw material. This research is aimed at replacing bakery fat in bread with African pear pulp and pulp oil, and studying the effects of various levels of such substitution on bread quality.

\section{MATERIALS AND METHODS Preparation of samples}


African pear fruits, commercial baker's grade wheat flour, bakery fat, baker's yeast, table salt and granulated sugar were purchased locally from a local market in Owerri, Nigeria. Ripe fruits were washed and seeds removed. The fruit pulp was slightly roasted/dried at $100^{\circ} \mathrm{C}$ for $10 \mathrm{~min}$ in an oven to enhance oil extraction. The pulp was ground using a manual grinder and the oil extracted using a screw press. The extracted oil was heated to remove moisture and then filtered through a muslim cloth. The fresh African pear pulp was also ground and used directly in the bread recipe. The quantity of oil supplied by the added pulp was calculated based on the oil content (20\%) of the African pear pulp used.

\section{Laboratory bread making and analysis.}

The African black pear pulp and pulp oil obtained were used to substitute the bakery fat at $0 \%, 25 \%, 50 \% 75 \%$ and $100 \%$ levels. The straight dough method was used (Pyke, 1976) and the ingredients used were flour (100gx) water (363ml), bakery fat $(2.4 \mathrm{~g})$ sugar $(2.4 \mathrm{~g})$ yeast $(\mathrm{g})$, salt $(1.7 \mathrm{~g})$. The height of the loaf was obtained by measuring the height of several slices of the loaf taken at different points. The length and width were obtained by measuring the base of loaf. The volume was then calculated by average of height $x$ length $x$ width. The loaf was weighed in an analytical balance to obtain the weight while density was calculated by mass/ volume. The proximate composition was analyzed by AOAC (1984) methods. The coded samples were presented to a 10-man test panel, who scored the samples based on a 9-point hedonic scale for taste, colour, crumb texture and overall acceptability.

\section{RESULTS AND DISCUSSION}

Production of a homogenous bread was possible because both the African pear pulp and pulp oil blended well into the bread dough. The effects of the different types of shortening on proximate composition and physical characteristics are shown on Table 1. The results showed that the type of shortening had significant effects $(\mathrm{p}<0.05)$ on most of the parameters investigated. However no significant difference was observed in the fat content of the bread samples. The protein content $(7.46 \%)$ for the control was not significantly different $(\mathrm{p}<0.05)$ from the protein content $(7.73 \%)$ of the bread prepared with pear pulp oil, but they were both significantly different $(\mathrm{p}<0.05)$ from the protein content $(9.40 \%)$ of the sample prepared with pear pulp. This suggests that a high protein bread could be produced using African pear pulp for special dietary purpose.

The values for the loaf height $(3.37 \mathrm{~cm})$ and loaf volume $(448.44 \mathrm{ml})$ were lowest for the sample containing African pear pulp though loaf weight (196.55g) was highest in it. This may be attributed to its high moisture $(52.48 \%)$, high fibre $(4.45 \%)$ and high protein $(9.46 \%)$ content. This explained why the loaf was denser, with low specific volume of $2.27 \mathrm{ml} / \mathrm{g}$ as against the control, which had specific volume of $3.37 \mathrm{ml} / \mathrm{g}$. Similar high fibre dense loaves have been obtained in bread produced with mango et al., 2005).

The effects of the level of substitution of the shortening on proximate composition and physical characteristics of the bread are shown on Table 2 . It was observed that the products differed significantly $(p<0.05)$ from the control almost in all the parameters investigated. The degree of difference increased as level of substitution increased. Bread height decreased as level of substitution increased. It was $4.53 \mathrm{~cm}$ at $0 \%$ level of substitution and $3.93 \mathrm{~cm}$ at $100 \%$ level of substitution. On the other hand, the loaf weight followed a reverse trend. It increased from $186 \mathrm{~g}$ for the control to $192.8 \mathrm{~g}$ at $100 \%$ level of substitution. A steady increase was observed in the protein, crude fibre, ash and moisture content of the bread with increased level of substitutions. But no significant ( $p>0.05)$ difference was observed in the fat content of all the samples. This suggests that highly nutritious bread could be obtained through substitution of the bakery fat with African black pear. mesocarp supplementation of the bread flour (Badifu 
The results of the sensory evaluation is shown in Table 2. A darker crumb colour was obtained with bread samples containing African pear pulp due to the blue-green colour of the pulp. Significantly lower $(\mathrm{p}<0.05)$ consumer scores $(3.2)$ were therefore obtained for colour. The scores for taste and aroma showed a moderate level of acceptance for African pear pulp substitution at $25 \%$. However the scores decreased significantly $(\mathrm{p}<0.05)$ with increase in the proportion of African pulp. The overall acceptability scores ranged from 5.8 to 7.4 for $0 \%$, $25 \%, 50 \%, 75 \%$ and $100 \%$ levels of pulp oil substitution. But the samples containing pear pulp had significantly lower scores in overall acceptability ranging from 3.3 to 5.6. However samples with $25 \%$ and $50 \%$ pear pulp substitution had moderate scores of 5.6 and 5.3 respectively. This suggests that the level of acceptance may improve with greater awareness of the product especially to those who prefer a dense, high protein, high fibre loaf. Bread samples produced with African pear oil were highly acceptable and competed favourably with the control sample.

\section{CONCLUSION}

This work has shown that acceptable bread could be produced using African pear pulp oil at appropriate level of substitution in bread recipe. It is also possible to produce high protein, high fibre bread for special dietary purposes by substituting the shortening with African pear pulp. This process will provide opportunity for industrial/commercial utilization of the African pear thereby reducing the extent of post harvest losses incurred.

\section{REFERENCES}

AOAC (1984): Official Methods of Analysis $15^{\text {th }}$ ed. Association of Official Analytical Chemists Washington DC, p 806-812.

Badifu G.I.O, Chima C.E. Ajayi Y.I and Ogori A.F. (2005) Influence of Mango Mesocarp flour supplementation to micronutrient, physical and organoleptic qualities of wheat based bread. Nig. Food Journal 23: 59-68.

Ihekoronye A.I and Ngoddy C. (1985): Integrated Food Science and Technology for the Tropics London Macmillan Pub. p 258-265.

Kinkella T. and Bezard J. (1993): Fat content and fatty acid composition of some food products from Congo. Original bottle: Less liprcles de quelques products alimentaires congolais. Science des Aliments 13(B): 567-575.

Mbofung C.M.F. Silou T and Mouragadja I. (2002): Chemical characterization of sajou (Dacryodes edulis) and evaluation of its potential as ingredient in nutritious biscuits. Trees and Livelihoods 12:105117.

Omoti U and Okiy D.A. (1987): Characterization and composition of the pulp oil and cake of the African Pear, Dacryodes edulis (Don G) Lam H.J. J.Sci Fd \& Agric 38(1): 805 - 809.

Pyke M. (1976). Food Science and Technology $3^{\text {rd }}$ ed. John Murray Pub, London, p 42 - 51. 
Table 1: Effect of type of shortening on proximate composition and physical parameters of wheat bread.

Parameter

Loaf Height $(\mathrm{cm})$

Loaf weight (gm)

Loaf volume (ml)

Specific volume

Protein (\%)

Carbohydrate (\%)

Fat $(\%)$

Crude fiber $(\%)$

Ash (\%)

Moisture (\%)
African pear pulp

$3.37^{\mathrm{a}}$
$196.55^{\mathrm{a}}$
$448.44^{\mathrm{a}}$
$2.21^{\mathrm{a}}$
$9.46^{\mathrm{a}}$
$49.33^{\mathrm{a}}$
$3.67^{\mathrm{a}}$
$4.45^{\mathrm{a}}$
$3.69^{\mathrm{a}}$
$52.48^{\mathrm{a}}$

Type of oil pear pulp

Commercial bakery fat

$\begin{array}{ll}4.80^{\mathrm{b}} & 4.53^{\mathrm{c}} \\ 186.75^{\mathrm{b}} & 186.00^{\mathrm{c}} \\ 647.07^{\mathrm{b}} & 627.30^{\mathrm{c}} \\ 3.45^{\mathrm{b}} & 3.37^{\mathrm{c}} \\ 7.73^{\mathrm{b}} & 627.30^{\mathrm{c}} \\ 39.60^{\mathrm{b}} & 24.49^{\mathrm{c}} \\ 3.80^{\mathrm{b}} & 3.56^{\mathrm{c}} \\ 2.51^{\mathrm{d}} & 1.70^{\mathrm{c}} \\ 2.22^{\mathrm{b}} & 1.50^{\mathrm{c}} \\ 44.31^{\mathrm{b}} & 36.13^{\mathrm{c}}\end{array}$

Means with the same superscript on the same row are not significantly different $(p>0.05)$ from each other

Table 2: Effect of level of shortening substitution on physical parameters and proximate composition of wheat bread.

\begin{tabular}{llllll}
\hline Parameter & \multicolumn{5}{c}{ Levels of substitution with African pear pulp oil } \\
\cline { 2 - 6 } & $\mathbf{0}$ & $\mathbf{2 5}$ & $\mathbf{5 0}$ & $\mathbf{7 5}$ & $\mathbf{1 0 0}$ \\
\cline { 2 - 5 } & $4.53^{\mathrm{a}}$ & $4.27^{\mathrm{b}}$ & $4.07^{\mathrm{c}}$ & $4.02^{\mathrm{c}}$ & $3.96^{\mathrm{c}}$ \\
Height (cm) & $186.00^{\mathrm{a}}$ & $189.65^{\mathrm{b}}$ & $190.65^{\mathrm{c}}$ & $193.50^{\mathrm{d}}$ & $192.80^{\mathrm{d}}$ \\
Weight (gm) & $627.30^{\mathrm{a}}$ & $584.30^{\mathrm{b}}$ & $537.75^{\mathrm{b}}$ & $565.26^{\mathrm{d}}$ & $504.01^{\mathrm{e}}$ \\
Volume $(\mathrm{ml})$ & $3.37^{\mathrm{a}}$ & $3.08^{\mathrm{b}}$ & $2.83^{\mathrm{c}}$ & $2.93^{\mathrm{d}}$ & $2.62^{\mathrm{c}}$ \\
Specific weight & $7.46^{\mathrm{a}}$ & $8.20^{\mathrm{b}}$ & $8.51^{\mathrm{bc}}$ & $8.71^{\mathrm{c}}$ & $8.96^{\mathrm{c}}$ \\
Protein \% & $49.33^{\mathrm{a}}$ & $35.48^{\mathrm{b}}$ & $34.43^{\mathrm{c}}$ & $32.56^{\mathrm{d}}$ & $27.70^{\mathrm{e}}$ \\
Carbohydrate\% & $3.56^{\mathrm{a}}$ & $3.68^{\mathrm{a}}$ & $3.65^{\mathrm{a}}$ & $3.83^{\mathrm{a}}$ & $3.78^{\mathrm{a}}$ \\
Fat $(\%)$ & $1.70^{\mathrm{a}}$ & $3.01^{\mathrm{b}}$ & $3.25^{\mathrm{bc}}$ & $3.50^{\mathrm{c}}$ & $4.16^{\mathrm{a}}$ \\
Crude fibre (\%) & $1.50^{\mathrm{a}}$ & $2.60^{\mathrm{b}}$ & $2.83^{\mathrm{bc}}$ & $3.11^{\mathrm{cd}}$ & $3.28^{\mathrm{d}}$ \\
Ash (\%) & $36.13^{\mathrm{a}}$ & $46.08^{\mathrm{b}}$ & $47.79^{\mathrm{c}}$ & $48.31^{\mathrm{c}}$ & $51.40^{\mathrm{d}}$ \\
Moisture (\%) & & & & & \\
\hline
\end{tabular}

Means with the same superscript on the same row are not significantly different $(p>0.05)$ from each other 
Table 3: Sensory characteristics of the different bread samples

\begin{tabular}{lccccc}
\hline Samples & Crumb & Taste & Aroma & Crumb & General acceptability \\
\hline CBS & $7.2^{\mathrm{a}}$ & $6.2^{\mathrm{a}}$ & $7.2^{\mathrm{a}}$ & $7.5^{\mathrm{a}}$ & $7.1^{\mathrm{a}}$ \\
Po1 & $7.2^{\mathrm{a}}$ & $6.1^{\mathrm{a}}$ & $6.8^{\mathrm{ab}}$ & $7.0^{\mathrm{a}}$ & $7.4^{\mathrm{a}}$ \\
Po2 & $6.2^{\mathrm{b}}$ & $5.7^{\mathrm{ab}}$ & $6.7^{\mathrm{ab}}$ & $6.7^{\mathrm{ab}}$ & $6.7^{\mathrm{ab}}$ \\
Po3 & $6.6^{\mathrm{b}}$ & $5.9^{\mathrm{ab}}$ & $6.3^{\mathrm{ab}}$ & $6.5^{\mathrm{a}}$ & $5.8^{\mathrm{bc}}$ \\
Po4 & $7.3^{\mathrm{a}}$ & $6.0^{\mathrm{ab}}$ & $6.1^{\mathrm{an}}$ & $6.7^{\mathrm{a}}$ & $5.3^{\mathrm{d}}$ \\
PP1 & $4.6^{\mathrm{ba}}$ & $5.2^{\mathrm{ab}}$ & $5.1^{\mathrm{c}}$ & $4.9^{\mathrm{b}}$ & $5.3^{\mathrm{d}}$ \\
PP2 & $4.5^{\mathrm{bc}}$ & $4.8^{\mathrm{bc}}$ & $4.7^{\mathrm{cd}}$ & $4.9^{\mathrm{b}}$ & $5.6^{\mathrm{cd}}$ \\
PP3 & $3.7^{\mathrm{cd}}$ & $3.4^{\mathrm{c}}$ & $4.1^{\mathrm{dc}}$ & $3.7^{\mathrm{c}}$ & $3.7^{\mathrm{c}}$ \\
PP4 & $3.2^{\mathrm{cd}}$ & $2.9^{\mathrm{c}}$ & $3.6^{\mathrm{c}}$ & $3.3^{\mathrm{c}}$ & $3.3^{\mathrm{c}}$ \\
\hline
\end{tabular}

Values on the same column with different subscripts are superscript significantly different $(p<0.05)$

$C B S=$

Pol =

Po2 $=$

Po3 =

Po4 =

$P P 1=$

$P P 2=$

$P P 3=$

PP4 =
Control bread sample

$25 \%$ pulp oil substitution

$50 \%$ pulp oil substitution

75\% pulp oil substitution

$100 \%$ pulp oil substitution

$25 \%$ pear pulp substitution

$50 \%$ pear pulp substitution

$75 \%$ pear pulp substitution

100\% pear pulp substitution 